\title{
Palm Oil Sustainable Management Using MDS Model from Social Dimension
}

\author{
Lili Dahliani \\ Vocasion School Bogor Agricultural Institute \\ teteh_lily@yahoo.com
}

\author{
Maya Dewi Dyah Maharani \\ Vocasion School Bogor Agricultural Institute \\ mayasudarsono@gmail.com
}

\begin{abstract}
Palm oil is a primary commodity that produces a variety of prospective and derivative industries. Data states that Indonesia'scontribution to the world crudepalmoil production is $47 \%$ of the world' sproduction. It is said that Indonesia is the world' slargest exporter of palmoil. The contribution of oil palm is derived from It srolewhichincludes regional and national economic contribution on Gross Domestic Product (GDP) income, employment, dividend payments and taxes to thegovernment, as well as various other forms of levies. Oil palm has also given an impact on the environment and human rights such as the decline of biodiversity and the issue of land rights. The negative impact will be minimized if the management of oil palm is carried out in sustainable way through social dimension, which includes 8 attributes. The study aims to determine the status of sustainability of palm oil management using Multi-Dimensional Scaling (MDS) model. MDS is a method used to assess sustainability status using RapPalm Oil software. The MDS technique uses the ALSCAL algorithm in a way that two object points or the same objects are mapped in a single point that is adjacenttoeach other. The results show that the social sustainability indexis $54.50 \%$. In order to sustain the palm oil management, intervention sonlabor absorption, accessibility of village communication, policy of synchronization, and social rule are required.
\end{abstract}

Keywords: commodity, palm oil, intervention, attribute

\section{INTRODUCTION}

Palm oil is one of the best commodities producing many kinds of industrial products which have prospects. Referring to an industrial tree, oil palm currently produces various down-stream industries and the achievement of a growing market share. The final productsof oil palm productionare food products and non-food products (oleokimia). Both of these different products produce cooking oil, red oil, sweetened condensed milk, margarine, emulsifier, which also can be processed to be a cattle fodder, pulp and paper, alcohol, compos, activated charcoal, organic solvent, lubricants, soap, candle, pharmacy product and cosmetics industry.
The Oilwood (2010) data stated that Indonesia has contributed up to $47 \%$ of world crude palm oil (CPO) production. This fact informs that Indonesia is claimed as the biggest CPO exporter country and makes Indonesia has a better bargaining power [1]. The CPO contribution to non-oil export value has tendency to increase. In 2014, the national CPO export has reached up to 17,464,905,000 USD.

The palm oil has economically been contributed to regional and national GDP through direct contribution on employment, dividend, government tax, and other retribution. Economically, the oil palm plantation in village area has positively decreased the gap for income. The empirical study outcome by Almasdi Syahza, the professor of Riau University, showed that it is not just increasing an index of farming community welfare but it also significantly reduces the income inequality both indistrict and city area. This is shown by Williamson index number that stated thereductionwas 0.5 in 2003 and 0.4 in 2005 and again 0.3 in 2007. The role of palm oil production to farming GDP, non-oil and gas GDP and total of GDP consecutively are $15.8 \%, 6 \%$ and $2.4 \%$.

The role of palm oil in employment in plantation subsector has been significant.Labor requirements on palm oil plantation subsector isnearly 6 millions people encompassing the administrative, harvest, transportation, processing and laboratory (Mangoensoekardjo S, 2005).

There has been many criticismon palm oil for giving a negative effect onenvironment, particularly when regional autonomy was implemented. According to Greenpeace report, the plantation expansion causes deforestation. For instance, it causes land fire issues. Consequently, it results in sustainable issues and it becomes a global strategic issue. Thus, the study focuses on anattempt to minimize the negative effect of oil plantation, so the palm oil management is needed. The sustainability is not merely the green growth only, but it must be inclusive (macro indicator) and exclusive (micro indicator). [2] said that sustainability development is to fulfillthe needs at this period of time without reducing the ability of future generations.

Measuring social sustainability must include both indicators. Micro indicator, measured on social sustainability ,not only includes level of company but also total EmploymentAbsorption and prosperity level created in palm oil companies and total palm oil farmers, planting due to the development of palm oil companies. Macro indicator measured with social sustainability includes benefits enjoyed by people around palm 
studied system had a sustainability index value greater than or equal to 50percent, then the system could be said to be sustainable, and unsustainable if the index value was less than 50 percent.

The stress value was described in Table 2 below:

Table2: Stress value

\begin{tabular}{lll}
\hline No & Stress value & Conformity \\
\hline 1 & $>20 \%$ & Bad \\
2 & $(10-20) \%$ & Enough \\
3 & $(5-10) \%$ & Good \\
4 & $(2,5-5) \%$ & Very good \\
\hline \multicolumn{2}{l}{ source: Kavanagh dan Pitcher $(2004)$}
\end{tabular}

Illustration of sustainability determination index was on an ordination scale at two extreme values ( 0 percent) bad and (100 percent)good.

Leverage analysis was implemented to determine the effect of stability if one attribute was omitted during ordination. The result of Leverage analysis indicated percentage of Root Mean Square (RMS) change in each attribute. Attributes possessing the highest percentage were the most sensitive attributes to sustainability [7] evaluated using Monte Carlo analysis, a statistical simulation method was applied to evaluate the effects of random error on the estimation process, and to evaluate the true value (Klahr, 1969).

\section{RESULT}

Based on the analysis conducted in this study, the value of social dimension index was $54.50 \%$, the value was in the range 50-74.99 percent or quite sustainable. The attributes expected to affect the social dimension consist of eight attributes; labor absorption, village communication accessibility, empowerment of oil palm farmers, settlement of land conflicts, fruit source harvest, law enforcement, policy synchronization, and social rules. The result of leverage attribute analysis was labor absorption (5.57), village communication accessibility (5.69), policy synchronization (5.64), and the social rule (5.61). Further attributes were the empowerment of oil palm farmers (4.76), settlement of land conflicts (4.35), fruit source feeding (4.20), and law enforcement (4.75).

The validation of the social dimension sustainability was analyzed by leverage aspect. Then Monte Carlo analysis was performed. In addition, the difference in the value of MDS calculation results with the relatively small Monte Carlo analysis was 0.90 or less. The validation of the Rap-Palm Oil simulation outcomesindicated that the explanatory or coefficient of determination (R2) had a quite high value of 0.910 meaning that the included eight attributeshad a significant role in explaining the diversity of palm oil management of the social dimension being built.

\section{CONCLUSION}

Attributive description indicating sustainable palm oil management for social dimensions are labor, communication access in village area, palm oil farmer, land conflict settlement, law reinforcement, policy synchronizations, and a social rule.

The attributes for labor absorption, communication access in rural area, policy synchronizations, and social rule have become a major priority in formulating scenario and sustainable palm oil management.

\section{SUGGESTION}

1. The use of Rap-Palm Oil is appropriate to assess the Sustainability Index (IKB) for Palm Oil Management in other development areas in Indonesia

2. Improvement for Palm Oil Management in Indonesia should be conducted by taking into consideration the improvement scores on labor attributes (5.57), village communication accessibility (5.69), policy synchronization (5.64), and social norms (5.61) to gain harmonization on economic and ecological dimensions.it is necessary to conduct them for realization of palm oil management sustainability in Indonesia

\section{REFERENCES}

[1] Sunarko,. Budidaya dan Pengolahan Kelapa Sawit, Meraari Bisnis Kelapa Sawit. Agromedia Pustaka. Jakarta (ID).2009

[2] Daniel M,. Prinsip dan Orientasi pembangunan Berkelanjutan, PT Grasindo . Jakarta (ID)2013

[3] Alder J, Pitcher TJ, Preikshot D, Kaschner K, Ferris B,.How good is good: A rapid appraisal technique for evaluationof the sustainability status of fisheries of North Atlantic Sea Around Us Method. 136-162. 2003

[4] Maharani Maya,. Model Pengelolaan Usaha Jasa Rumah Potong Hewan Ruminansia secara berkelanjutan. Disertasi Program Pasca Sarjana IPB. 2015

[5] Mersyah, R. Desain system budidaya sapi potong berkelanjutan untuk mendukung pelaksanaan otonomi daerah di Kabupaten Bengkulu selatan. Disertasi Program Pasca Sarjana. 2005,

[6] Ridwan, W.A. Model agribisnis Peternakan Sapi Perah Berkelanjutan Pada Kawasan Pariwisata di Kabupaten Bogor. Disertasi Program Pasca SarjanalPB. 2006.

[7] Kavanagh, P. Rapid Appraisal for fisheries project. Rafish Software Description for Microsoft Excel.University of BritishColumbia Fisheries Center Vancouver.2001.

[8] Ahad A, Blanchard F, Guyader O, Sustainability of tropical small scale fisheries: Integrated assessment in French Guiana.Marine Policy, February 2014, Vol 44, pages 397-405. 2014.

[9] Fauzi, A. dan Anna., Pemodelan sumberdaya perikanan dan kelautan untuk analisisk ebijakan. 
PT. GramediaPustakaUtama., Jakarta. Pp 343. 2005.

[10] Geoffrey, G, Roy. The use of multi dimensional scaling in policy selection.Journal of the Operational Research Society 33: 239-245. 1982.

[11] Simbolon Amran B, Erlinda Y, AdiSuyatno, Kontribusi Kebun Plasma Terhadap Keuntungan
Kebun Ngabang PT Perkebunan Nusantara XIII (Persero), Jurnal Social Economic of Agriculture. Vol. 2,No. 2.Desember 2013.Hlm. 68-74. 2013.

[12] World Bank,. Inclusive Green Growth: The Pathway to Sustainable Development. Oil Word Annual Report. 2013 